\title{
Medical education as mission
}

\section{J Dwight Phillips ${ }^{\mathrm{a}}$ and James D Smith ${ }^{\mathrm{b}}$}

${ }^{a} \mathrm{MD}$, Professor of Pediatrics, Department of Pediatric and Adolescent Medicine, Mayo Clinic, Rochester, Minnesota, USA

${ }^{\mathrm{b}} \mathrm{MD}$, Professor Emeritus, Otolaryngology, Oregon Health and Science University, Portland, Oregon, USA

We appreciate the insightful commentary of Dr. Mark Crouch in his article The Propper College, ${ }^{1}$ some of which was stimulated by our articles in an earlier issue of $\mathrm{CJGH}^{2}$ In fact, we heartily agree with Dr. Crouch and add these additional comments to further emphasize some of the important points he raised.

First, clinical medicine has value! No matter how excited we are and become about medical education as missions, we agree with Dr. Crouch's plea: "Don't forsake clinical medicine." As Crouch clearly pointed out, Jesus preached and healed. Life is multi-faceted. Ministry is multi-faceted. Jesus saw crowds with compassion and urged His disciples to pray for more laborers - laborers who would compassionately work to help needy people. Jesus Himself demonstrated the value of clinical medicine as He saw the opportunity to heal as an emergent reason to "break" a Sabbath law, and as he linked spiritual healing and physical cure as concurrent activities in patients who sought Him. God directs each of us to balance many opportunities - teaching medicine, preaching the Gospel, healing the sick, caring for the dying, studying existing problems. We show our multi-faceted love for God as we love Him with our heart and soul and mind and strength. Education is important, and some of us get to concentrate a lot of time and effort on education; but, this does not in any way decrease the importance of practicing clinical medicine.

Second, humility matters! Crouch wisely said that those who take on "the mantle of teacher" are required to demonstrate humility. Indeed, every Christian, health worker or not, is called to humility. Examples abound of well-intentioned missionaries who caused unintended harm due to arrogance. Readers of The Poisonwood Bible as well as readers of When Helping Hurts are graphically reminded of the importance of humility in medical missions. We all need to grow in humility. We must, as Crouch clearly states, recognize the limitations of our training and knowledge. We must keep learning - about local illnesses, about cultural variations, and about effective ministry. We must daily avoid power differentials whereby "we" hold the power over "them," be it by "us" being healthier or wealthier or more educated or taller or whiter or louder. God, through Paul, calls us to be transformed by the renewal of our minds; we must humbly keep learning. We must recognize limitations. We must be willing to learn, even from those we came to serve.

Third, teaching must be relevant! We each have the privilege of teaching in many parts of the world, and we do not repeat the same "lessons" in each setting. Medical training must be adapted and relevant based on local disease epidemiology, diagnostic means, and feasible treatment resources. Some basic science facts remain relevant across geographic boundaries, but the application of scientific knowledge must be made relevant in various situations. In addition, treatment must be communicated clearly across cultural and linguistic barriers. Effective teaching requires adequate understanding of local situations. One visiting short-term medical missionary knew that her young age and female gender might not be respected in the male-dominated area she was visiting. A man

July 2018. Christian Journal for Global Health 5(1):50-52. 
entered the exam room with a clinic card on which the chief complaint, "swelling in groin," was written. She greeted the man and asked him to drop his pants. He stared at her, incredulous. Prepared for being disrespected, she firmly explained, "I am the doctor. Drop your pants." Her words had to be repeatedly translated before he complied. She then carefully examined his genital anatomy and explained, "Everything is normal. There is no problem." "Of course," he exclaimed, flabbergasted and still naked, pointing across the room to his son saying, "He's the patient." In clinical care and in educational ministry, we must always understand local situations before imposing our knowledge on others.

Fourth, focus properly! Jesus is building His Church, and He calls us to participate relationally with individuals and with groups of people. It is not necessarily our responsibility to build institutions. The goal is to see people grow to true whole-person health: physically, emotionally, mentally, and spiritually. The goal is not to sustain institutions but, rather, to help people as Jesus builds His eternal institution. Very few medical institutions are financially sustainable; essentially, all either depend on governmental help or philanthropic donations to continue functioning. The call to appropriate stewardship of resources is wise, but service is the goal, not sustainability. Crouch wisely urges us to keep our focus, whether caring or educating, on people rather than on institutional structures. We affirm this, even as the institution where one of us works (Mayo Clinic) says, "The needs of the patient come first." Patient centricity has been effective as Mayo Clinic has grown to be a leading medical institution in the world, with a highly ranked medical school and active research activities. Focus on people!

Finally, modeling matters! We have heard details about the work of Mark Crouch in Asia. We have observed as he taught in the United States. We have read and re-read his helpful writing in CJGH. Mark Crouch is a role model, and, we should all be role models. We teach by our actions. True education is much more than the transmission of information; it involves changing lives as people learn how to act based on proper information. Jesus taught in sermons, through stories, and while serving. Care and education should benefit whole persons, and models such as PRIME $^{3}$ are helpful in guiding learners toward whole person care. All education should be multi-faceted. Teachers living by the "medical education as mission" framework espoused in $\mathrm{CJGH}$ will communicate factual knowledge. They will help learners understand new information, and they will model the implementation of improved patient care.

We are grateful for the comments of Mark Crouch, comments to keep educators relevant and real, humble and helpful, and compassionate and kind. Like Crouch, and like Jesus, we can all join in ministry around the world, ministry that involves a personalized mix of clinical care and educational expertise.

\section{References}

1. Crouch M. The proper college. Christian Journal for Global Health 2017;4(1):30-3.

https://doi.org/10.15566/cjgh.v4i1.157

2. Smith JD, Holland RP, Phillips JD, Falkenheimer

SA. Mobilizing and training academic faculty for medical mission: current status and future directions. Christian Journal for Global Health 2016;3(2):168-75. https://doi.org/10.15566/cigh.v3i2.134

3. Morgan H. PRIME partnerships in international medical education - restoring a Christian ethos to medical education worldwide. Christian Journal for Global Health 2016;3(2):134-9.

https://doi.org/10.15566/cjgh.v3i2.127 
Competing Interests: None declared.

Correspondence: J Dwight Phillips, Department of Pediatric and Adolescent Medicine, Mayo Clinic, United States of America. jdwightphillips@gmail.com

Cite this article as: Phillips J D, Smith J D. Medical education as mission. Christian Journal for Global Health. July 2018; 5(1):50-52. https://doi.org/10.15566/cjgh.v5i1.214

(C) Phillips J D, Smith J D. This is an open-access article distributed under the terms of the Creative Commons Attribution License, which permits unrestricted use, distribution, and reproduction in any medium, provided the original author and source are properly cited. To view a copy of the license, visit http://creativecommons.org/licenses/by/4.0/

www.cjgh.org

July 2018. Christian Journal for Global Health 5(1):50-52. 